\title{
EFEKTIFITAS MEDIASI DALAM PENYELESAIAN SENGKETA KONSUMEN PADA BADAN PENYELESAIAN SENGKETA KONSUMEN (BPSK) KOTA BUKITTINGGI TAHUN 2014-2017
}

\author{
Bustamar \\ Fakultas Syariah IAIN Bukittinggi \\ Jl. Paninjauan Garegeh Bukittinggi \\ e-mail: bustamar22@gmail.com
}

\begin{abstract}
Mediation in the settlement of consumer disputes at BPSK Bukittinggi Year 2014-2017 run effectively. 18 of the 33 cases registered in the Bukittinggi BPSK from 2014 to July 2017 were settled by means of mediation, with the remaining 15 cases settled by arbitration. The effectiveness of such mediation is supported by Law no. 8 in 1999 and Kemendag no. 350 / MPP / Kep / 12/2001 which despite the perceived many weaknesses and need improvement, but with the presence of 9 members of the Bukittinggi BPSK assembly which majority of law educated and 3 of them are certified mediators and the existence of adequate facilities can be a counterweight and reinforcement mediation process as well as driving the legal culture of the parties to the dispute.
\end{abstract}

Kata kunci: efektifitas, mediasi, BPSK Bukittinggi

\section{PENDAHULUAN}

B adan Penyelesaian Sengketa Konsumen (untuk selanjutnya disebut BPSK) merupakan salah satu lembaga non litigasi yang bertugas dan berwenang memeriksa, menyelesaikan dan memutus sengketa antara konsumen dengan produsen atau pelaku usaha dalam penggunaan barang dan jasa yang bukan untuk diperdagangkan. Konsumen adalah setiap orang pemakai barang dan atau jasa yang tersedia dalam masyarakat, baik bagi kepentingan diri sendiri, keluarga, orang lain maupun makhluk hidup lain dan tidak untuk diperdagangkan. (Pasal 1 angka 2 UU No. 8 Tahun 1999)

Sengketa konsumen adalah sengketa berkenaan dengan pelanggaran hak-hak konsumen. (Praditya, 2008: 135) Lingkupnya mencakup semua segi hukum, baik keperdataan, pidana maupun tata Negara. Oleh karena itu, tidak digunakan istilah "sengketa transaksi konsumen" karena yang terakhir ini berkesan lebih sempit, yang hanya mencakup aspek hukum keperdataan. Adapun hak-hak konsumen yang diatur dalam UU Perlindungan Konsumen adalah sebagai berikut : (Pasal 4 UU No. 8 Tahun 1999).

1. hak atas kenyamanan, keamanan, dan keselamatan dalam mengkonsumsi barang dan atau jasa;

2. hak untuk memilih barang dan atau jasa serta mendapatkan barang dan atau jasa tersebut sesuai dengan nilai tukar dan kondisi serta jaminan yang dijanjikan; 
Apabila hak-hak konsumen di atas tidak terpenuhi sebagaimana mestinya maka berpotensi menimbulkan sengketa konsumen, sengketa mana permohonan penyelesainnya dapat ditempuh melalui jalur litigasi ke pengadilan dalam lingkungan peradilan umum maupun melalui jalur non litigasi ke BPSK atas pilihan sukarela para pihak.

Jika permohonan penyelesaian sengketa diajukan ke Pengadilan dalam Lingkungan Peradilan Umum tentu proses penyelesaiannya tunduk para hukum acara perdata pada umumnya yang diawali dengan proses mediasi sesuai dengan ketentuan Peraturan Mahkamah Agung RI No. 1 Tahun 2016 tentang Mediasi di Pengadilan. Sedangkan apabila proses permohonan penyelesaian sengketa konsumen diajukan BPSK maka proses penyelesaiannya dilakukan melalui tiga alternatif, yaitu mediasi, konsiliasi dan atau arbitrase. (Kemendag No. 350/MPP/Kep/12/2001)

BPSK Kota Bukittinggi sebagai salah satu BPSK yang dibentuk pemerintah. Dari ketiga alternatif penyelesaian sengketa konsumen pada BPSK di atas, mediasi merupakan cara penyelesaian sengketa yang banyak diterapkan di BPSK Kota Bukittinggi atas pilihan dan kesepakatan para pihak yang bersengketa.

Dari survey awal diketahui bahwa dari 8 Perkara yang didaftarkan ke BPSK Bukittinggi tahun 2014, 5 perkara diantaranya diselesaikan dengan cara mediasi dan sisanya 3 perkara diselesaikan melalui arbitrase. Tahun 2015, 7 dari 12 perkara diselesaikan melalui mediasi dan sisanya 5 perkara melalui arbitrase. Sedangkan tahun 2016 dari 11 perkara yang terdaftar di sekretariat BPSK Bukittinggi, 4 diselesaikan melalui mediasi dan sisanya 7 perkara melalui arbitrase. Sedangkan pada tahun 2017 sampai berakhirnya jambatan majelis BPSK periode 2011-2017 pada bulan Juli 2017, terdapat 2 perkara yang dapat diproses oleh BPSK Bukittinggi dan keduanya diselesaikan dengan cara mediasi. (Laporan BPSK Bukittinggi, 2014, 2015, 2016, dan 2017)

Beranjak dari fakta di atas, penelitian ini dimaksudkan untuk menganalisis mengenai efektifitas Pelaksanaan Mediasi Dalam Penyelesaian Sengketa Konsumen Pada BPSK Kota Bukittinggi. Teori yang digunakan sebagai pisau analisis adalah teori efektifitas hukum yang di elaborasi dengan konsep Penyelesaian sengketa konsumen melaui cara mediasi sebagai alternatif penyelesaian sengketa konsumen pada BPSK.

\section{METODE PENELITIAN}

Penelitian yuridis empiris ini mengambil lokasi penelitian di Badan Penyelesaian Sengketa Konsumen (BPSK) Kota Bukittinggi. Teknik pengumpulan data primer menggunakan wawancara. Wawancara dilakukan terhadap informan kunci yang dipilih secara purposive berkembang mengikuti prinsip snowball. Teknik pengumpulan data sekunder, menggunakan studi literer. Teknik analisis menggunakan Interactive Model dari Miles dan Huberman.

\section{PEMBAHASAN}

\section{Kondisi Umum BPSK Kota Bukittinggi}

Kota Bukittinggi (bahasa Minang: Bukiktinggi; Jawi, بوكيقن: adalah kota terbesar kedua di Provinsi Sumatera Barat, Indonesia. (Bukittinggi dalam Angka: 2016) Kota ini 
pernah menjadi ibu kota Indonesia pada masa Pemerintahan Darurat Republik Indonesia. (Mestika Zet, Hadi Utama \& Hasril Caniago, 1995) Kota ini juga pernah menjadi ibu kota Provinsi Sumatera dan Provinsi Sumatera Tengah. Kota ini pada zaman kolonial Belanda disebut dengan Fort de Kock dan mendapat julukan sebagai Parijs van Sumatra. Bukittinggi dikenal sebagai kota perjuangan bangsa dan merupakan tempat kelahiran beberapa tokoh pendiri Republik Indonesia, di antaranya adalah Mohammad Hatta dan Assaat yang masing-masing merupakan proklamator dan pejabat presiden Republik Indonesia.

Kota Bukittinggi terletak pada rangkaian Pegunungan Bukit Barisan atau sekitar $90 \mathrm{~km}$ arah utara dari Kota Padang. Kota ini berada di tepi Ngarai Sianok dan dikelilingi oleh dua gunung yaitu Gunung Singgalang dan Gunung Marapi. Lokasinya pada ketinggian 909-941 meter di atas permukaan laut menjadikan Bukittinggi kota berhawa sejuk dengan suhu berkisar antara $16.1-24.9^{\circ} \mathrm{C}$. Luas Bukittinggi secara de jure adalah $145,29 \mathrm{~km}^{2}$, mengacu pada Peraturan Pemerintah nomor 84 tahun 1999. (http://penataanruang. pu.go.id/bulletin/index.asp?mod=_fullar t\&idart=94, diakses tanggal 12 Juli 2017) Namun secara de facto saat ini, Bukittinggi masih seluas $25,24 \mathrm{~km}^{2}$ karena sebagian masyarakat Kabupaten Agam menolak perluasan wilayah tersebut.

Kota Bukittinggi merupakan salah satu pusat perdagangan grosir terbesar di Pulau Sumatera. Pusat perdagangan utamanya terdapat di Pasar Atas, Pasar Bawah, dan Pasar Aur Kuning. Dari sektor perekonomian, Bukittinggi merupakan kota dengan PDRB terbesar kedua di Sumatera
Barat, setelah Kota Padang. Bukittinggi juga dikenal sebagai kota wisata terkemuka dan bersaudara (sister city) dengan Seremban di Negeri Sembilan, Malaysia. Tempat wisata yang ramai dikunjungi adalah Jam Gadang, yaitu sebuah menara jam yang terletak di jantung kota sekaligus menjadi simbol bagi Bukittinggi.

Sebagai kota perdagangan barang dan jasa, di Bukittinggi juga dilengkapi dengan keberadaan Badan Penyelesaian Sengketa Konsumen (BPSK) yang didirikan oleh pemerintah dan mulai beroperasi pada tahun 2011. Sekretariat BPSK Kota Bukittinggi terletak di Jl. Perwira No. 184, Belakang Balok Kota Bukittinggi.

Menurut Alizar yang sehari-hari sebagai Kepala Sekretariat BPSK kota Bukittinggi, anggota BPSK kota Bukittinggi pertama kali dilantik pada tahun 2011 sebanyak 9 orang majelis yang terdiri dari perwakilan tiga unsur, yaitu unsur pemerintah, unsur konsumen dan unsur pelaku usaha. Unsur pemerintah diwakili oleh Ali Rahman, SH., MH, H. Bustamar, S. Ag., MH, dan Rudolv Satri, $\mathrm{SH}$, unsur konsumen diwakili oleh Indra Jaya, SH, Gusri El Faisal, S.HI, dan Ramdalel, S.Sos, sedangkan unsur pelaku Usaha diwakili oleh Drs. H. Zulkifli Joneva, SH., MM, Ir. Asnal Zakri., MM, dan Nasrul Fitra, SH. dengan masa bakti 2011-2017 (Alizar, Wawancara Pribadi, 5 Juli 2017)

Lebih lanjut Alizar menuturkan, bahwa dalam perjalanannya kemudian terjadi pergantian antar waktu terhadap tiga anggota majelis BPSK Kota Bukittinggi karena anggota majelis atas nama Nasrul Fitra, SH dan Ramdalel, S, Sos mengundurkan diri sebagai anggota 
BPSK Bukittinggi karena yang bersangkutan maju sebagai calon anggota legislatif pada Pemilu Legislatif tahun 2014, dan sebagi gantinya dilantik Novia Alamsyah, SH dan Doni, S.HI. pada tahun 2016 Doni, S.HI pun mengundurkan diri sebagai anggota majelis BPSK Bukittinggi karena yang bersangkutan dianggkat sebagai Komisioner Komisi Pemilihan Umum (KPU) Kota Bukittinggi penggantian antar waktu. Sampai mengakhiri masa bakti anggota majelis BPSK Bukitinggi periode I 2011-2017 hanya tinggal 8 orang, masing-masing 3 dari unsur pemerintah, 3 dari unsur pelaku usaha dan 2 dari unsur konsumen.

Dalam menjalankan tugasnya BPSK Kota Bukittinggi dibantu oleh sekretariat yang terdiri dari 5 orang yang terdiri dari kepala sekretariat dan anggota sekretariat, terakhir dijabat oleh Drs. Alizar sebagai kepala sekretariat, Silviyanti, SE, H. Dondi Putra, A.Md, Joko Naolo, S.Sos, dan Refda Ningsih, A.Md, masing masing sebagai anggota sekretariat. Kepala dan Anggota sekretariat sekaligus merangkap sebagai panitera BPSK Kota Bukittinggi. (Silvianti, Wawancara Pribadi, 11 Juli 2017)

Sepanjang perjalanannya, BPSK Kota Bukittinggi senantiasa aktif merespon berbagai perkara sengketa konsumen yang diajukan kepadanya, diantaranya dalam bentuk konsultasi, dan sebahagian besar kemudian berlajut sebagai perkara sengketa konsumen yang diselesaikan melalui mekanisme penyelesaian sengketa konsumen dalam bentuk mediasi, konsiliasi ataupun arbitrase.

Menurut data BPSK Kota Bukittinggi, pada Tahun 2014 dapat diselesaikan 8 perkara, 2015 sebanyak 12 perkara, 2016 sebanyak 13 perkara dan tahun 2017 sebanyak 2 perkara.
Fakta itu menunjukkan bahwa BPSK Kota Bukittinggi termasuk BPSK yang aktif di Sumatera Barat, dan mayoritas proses penyelesaian sengketa pada BPSK Bukittinggi dapat diselesaikan dengan jalan mediasi dengan penekanan pada prinsip win-win solution dimana penyelesaian dicapai dengan kesepakatan para pihak yang bersengketa dengan mengedepankan perdamaian.

\section{Mediasi sebagai Alternatif Penyelesaian Sengketa Konsumen}

Penyelesaian sengketa konsumen dilakukan dengan berpedoman kepada hukum perlindungan konsumen. (Susantu Adi Nugroho, 2015: 57) Hukum Perlindungan konsumen merupakan bagian dari hukum konsumen. Pengertian konsumen sendiri terdiri dari 3 (tiga) pengertian yaitu konsumen, konsumen antara dan konsumen akhir (Susantu Adi Nugroho, 2015: 57) :

1. Konsumen adalah setiap orang yang mendapatkan barang dan atau jasa yang digunakan untuk tujuan tertentu;

2. Konsumen antara adalah setiap orang yang mendapatkan barang dan atau jasa yang digunakan untuk diperdagangkan/ komersial.

3. Konsumen akhir adalah setiap orang alami (natuurlijke persoon) yang mendapatkan barang dan atau jasa, yang digunakan untuk tujuan memenuhi kebutuhan hidup pribadinya, keluarga dan atau rumah tangganya dan tidak untuk diperdagangkan kembali.

Penyelesaian sengketa konsumen menurut UU No. 8 Tahun 1999 dapat ditempuh melaui jalur litigasi ke pengadilan dalam lingkungan peradilan umum dan melalui jalur non litigasi diluar 
pengadilan diantaranya dapt diajukan ke BPSK, dengan mediasi termasuk salah satu diantara tiga alternative penyelesaian sengketa konsumen melalui BPSK.

Istilah mediasi berasal dari bahasa Latin "mediare" yang berarti "ditengahtengah" sedangkan definisi mediasi dapat dibaca dalam berbagai literatur, di antaranya definisi dari Moore yang berbunyi: "the intervention in a negotiation or a conflict of an acceptable third party who has limited or no authotitative decision making power, who assists the involved parties in voluntary reaching a mutually accectable settlement ofissues in dispute.,, (Christopher W. Moore, 2003: 15 Sri Mamudji, 2004: 194)

Definisi lain mediasi menurut NolanHaley adalah: "a shortterm, structured, task oriented, participatory intervention process. Diputing parties work with a neutral third party, the mediator, to reach amutually acceptable agreement." (Nolan-Haley, NolanHaley, Jacqueline M., 1992: 56 dalam Sri Mamudji, 2004: 194)

Definisi mediasi menurut Kovach: "facilitated negotiation. It is process by which a neutral third party, the mediator, assists disputing parties in reaching a mutually satisfactory resolution." (Kimberlee K. Kovach, 1994: 16 dalam Sri Mamudji, 2004: 194)

Dari berbagai definisi mediasi yang telah diuraikan di atas, dapat disimpulkan bahwa di dalam pengertian tersebut terdapat unsur-unsur yang dapat dikategorikan sebagai ciri mediasi, sebagai berikut:

1. mediasi adalah negosiasi lanjutan;

2. dibantu oleh pihak ketiga yang netral dan tidak berpihak;
3. pihak ketiga tidak mempunyai wewenang untuk memutus;

4. keberadaan pihak ketiga diterima oleh para pihak; bertujuan untuk menyelesaikan sengketa berdasarkan kesepakatan yang memuaskan.

Garry Goopaster memberikan definisi mediasi sebagai proses negosiasi pemecahan masalah di mana pihak luar yang tidak memihak (imparsial) bekerja sama dengan pihak-pihak yang bersengketa untuk membantu mereka memperoleh kesepakatan perjanjian untuk memuaskan. (Mochamad Samsukadi \& Ahmad Abdu, 2016: 5) Pemaparan Goopaster tampaknya mencoba mengeksplorasi lebih jauh tentang makna mediasi yang tidak hanya dalam pengertian bahasa, tetapi ia juga menggambarkan bagaimana alur proses kegiatan mediasi, kedudukan dan peran pihak ketiga, serta tujuan dilakukannya mediasi dalam penyelesaian sengketa.

Hal yang kurang lebih sama dikemukakan oleh Takdir Rahmadi, mediasi adalah suatu proses penyelesaian sengketa antara dua pihak atau lebih melalui perundingan atau cara mufakat dengan bantuan pihak netral yang tidak memiliki kewenangan memutus. Pihak netral tersebut disebut mediator dengan tugas memberikan bantuan prosedural dan substansial. (Takdir Rahmadi, 2010: 12-13)

Pengaturan mengenai mediasi di luar pengadilan dalam hukum Positif di Indonesia dapat kita temukan dalam HIR Pasal $130(\mathrm{HIR}=$ Pasal $154 \mathrm{RBg}=$ Pasal 31 Rv, ketentuan Pasal 6 ayat (3), (5), Undang-undang No. 30 Tahun 1999 Arbitrase dan Alternatif Penyelesaian Sengketa. Sedangkan mediasi di BPSK dalam Keputusan Menteri Perindustrian 
190

dan Perdagangan No. 350/MPP/Kep/12/2001. Dalam ketentuan Pasal 1 angka 10 Mediasi adalah proses penyelesaian sengketa konsumen di luar pengadilan dengan perantaraan BPSK sebagai penasehat dan penyelesaiannya diserahkan kepada para pihak.

Alur proses mediasi di BPSK diatur dalam Pasal $30 \quad$ Kemendag 350//MPP/Kep/12/2001 sebagai berikut : "Majelis dalam menyelesaikan sengketa konsumen dengan cara Mediasi, mempunyai tugas :

1. memanggil konsumen dan pelaku usaha yang bersengketa;

2. memanggil saksi dan saksi ahli bila diperlukan;

3. menyediakan forum bagi konsumen dan pelaku usaha yang bersengketa;

4. secara aktif mendamaikan konsumen dan pelaku usaha yang bersengketa;

5. secara aktif memberikan saran atau anjuran penyelesaian sengketa konsumen

6. sesuai dengan praturan perundangundangan di bidang perlindungan konsumen.

Lebih lanjut dalam Pasal 31 Kemendag dinyatakan bahwa tata cara penyelesaian sengketa konsumen dengan cara Mediasi adalah :

1. Majelis menyerahkan sepenuhnya proses penyelesaian sengketa kepada konsumen dan pelaku usaha yang bersangkutan, baik mengenai bentuk maupun jumlah ganti rugi;

2. Majelis bertindak aktif sebagai Mediator dengan memberikan nasehat, petunjuk, saran dan upaya-upaya lain dalam menyelesaikan sengketa; Majelis menerima hasil musyawarah konsumen dan pelaku usaha dan mengeluarkan ketentuan.

\section{Hasil Penelitian}

Efektifitas Pelaksanaan Mediasi dalam Penyelesaian Sengketa Konsumen Pada BPSK Kota Bukittinggi

Efektifitas mediasi dalam penyelesaian sengketa konsumen pada BPSK Bukittinggi tahun 2014-2017 dalam pembahasan ini akan dianalisis dengan teori efektifitas hukum. Menurut Lawrence M. Friedman, efektifitas hukum dipengaruhi oleh tiga faktor penting antara lain: substansi hukum; struktur hukum dan; kultur hukum. Ketiga faktor ini sangat tergantung satu sama lainnya, karena apabila substansi hukumnya sudah baik harus didukung oleh struktur hukum yang baik pula, demikian juga kultur hukum sangat mempengaruhi dua faktor yang lainnya. Kultur hukum ini yang akan melahirkan kesadaran hukum.

Pemikiran Friedman, dipertegas oleh Soerjono Soekanto bahwa, untuk mengukur efektifitas pelaksanaan suatu peraturan hukum mesti dilihat dari beberapa faktor, diantaranya adalah: pertama, dikembalikan pada hukum itu sendiri (substansi hukum) ; kedua, para petugas yang menegakannya (struktur hukum); ketiga, fasilitas yang mendukung pelaksanaan hukum; keempat, warga masyarakat yang terkena peraturan (budaya hukum) (Soerdjono Soekanto, 1981: 47-52).

Berpedoman pada pemikiran tersebut di atas, maka efektifitas pelaksanaan mediasi dalam penyelesaian sengketa konsumen di BPSK Bukittinggi akan dianalisis dari beberapa aspek, antara lain: pertama, dikembalikan pada 
hukum itu sendiri (substansi hukum); kedua, para petugas yang menegakannya (struktur hukum); ketiga, fasilitas yang mendukung pelaksanaan hukum dan ; keempat, warga masyarakat yang terkena peraturan (budaya hukum).

Substansi hukum dalam penelitian ini dikembalikan pada keententuan perundang-undangan yang di pedomani oleh BPSK dalam menjalankan tugas dan fungsinya dan dalam melaksanakan mediasi dalam penyelesaian sengketa konsumen. Dalam hal ini peraturan perundang-uangan dimaksud adalah UU No. 8 Tahun 1999 Tentang Perlindungan Konsumen dan Kemendag 350//MPP /Kep/12/2001 Tentang Pelaksanaan Tugas dan Wewenang Badan Penyelesaian Sengketa Konsumen.

Para petugas hukum merupakan anggota majelis BPSK kota Bukittinggi yang berjumlah 9 orang yang terdiri dari 3 orang berasal dari usur pemerintah, 3 orang unsur pelaku usaha dan 3 orang dari unsur konsumen.

Fasilitas yang mendukung adalah ketersediaan sarana dan prasara yang memadai guna memberikan kenyamanan suasana dalam pelaksanaan mediasi, ketersediaan ruangan mediasi dengan design yang sesuai tentu bahagian penting untuk sukses atau tidaknya proses mediasi.

Sedangkan budaya hukum masyarakat akan ditelusuri melalui rekam jejak proses mediasi, karena budaya hukum dan itikad baik para pihak yang dimediasi adalah kata kunci yang sangat besar pengaruhnya dalam keberhasilan mediasi disamping faktor yuridis, sumber daya manusia hukum dan saranaprasarana pendukung.
Rentang tahun 2014- Juli 2017 jumlah perkara diperoleh bahwa dari 8 Perkara yang didaftarkan ke BPSK Bukittinggi tahun 2014, 5 perkara diantara diselesaikan dengan cara mediasi dan sisanya 3 perkara diselesaikan melalui arbitrase. Tahun 2015, 7 dari 12 perkara diselesaikan melalui mediasi dan sisanya 5 perkara melalui arbitrase. Sedangkan tahun 2016 dari 11 perkara yang terdaftar di sekretariat BPSK Bukittinggi, 4 diselesaikan melalui mediasi dan sisanya 7 perkara melalui arbitrase. Sedangkan pada tahun 2017 sampai berakhirnya jambatan majelis BPSK periode 2011-2017 pada bulan Juli 2017, terdapat 2 perkara yang dapat diproses oleh BPSK Bukittinggi dan keduanya diselesaikan dengan cara mediasi. (Silvianti, Wawancara Pribadi, 10 Juli 2017)

Data di atas menunjukkan bahwa rentang waktu 2014-Juli 2017 menunjukkan bahwa jumlah perkara yang didaftarkan di BPSK Bukittingg adalah sebanyak 33 perkara dan 18 perkara diselesaikan melalui mediasi, sisanya 15 perkara melalui arbitrase. Dengan demikian dapat disimpulkan bahwa mayoritas perkara sengketa konsumen yang terdaftar di BPSK kota Bukittinggi pada tahun 2014-Juli 2017 diselesaikan dengan cara mediasi atas pilihan sukarela para pihak yang bersengketa.

Apabila pelaksanaan mediasi dalam penyelesaian sengketa konsumen di BPSK Kota Bukittinggi di atas dianalisis dengan teori efektifitas hukum, maka penjelsanannya dapat dikemukakan sebagai berikut: 


\section{Faktor Yuridis}

Dalam menjalankan tugas dan kewenangannya BPSK berpedoman kepada peraturan perundang-undangan terkait, diantara yang secara langsung mengtur keberadaan BPSK adalah :

a. UU No. 8 Tahun 1999 Tentang Perlindungan Konsumen

b. Kemendag 350//MPP/Kep/12/2001 Tentang Pelaksanaan Tugas dan Wewenang Badan Penyelesaian Sengketa Konsumen.

Keberadaan UU No. 8 Tahun 1999 Tentang Perlindungan Konsumen merupakan dasar hukum pembentukan BPSK. Sedangkan Kemendag 350//MPP/ Kep/12/2001 mengatur tentang tugas dan weweng BPSK, aturan ini biasa disebut juga dengan hukum acara BPSK dalam menangani sengketa konsumen.

Menurut Asnal Zakri dan Gusri El Faisal, (Wawancara Pribadi, 10 Juli 2017) yang sehari-hari sebagai anggota majelis di BPSK Kota Bukittinggi, meskipun secara yuridis formal Kemendag 350/MPP/Kep/12/2001 adalah hukum acara yang dapat dipedomani oleh BPSK dalam meyelesaikan sengketa konsumen, namun keberadaanya sebagai hukum acara belum dirasa memadai karena terdapat berbagai hal tidak pada tempatnya. Akan tetapi Kemendag 350/MPP/Kep/12/2001 adalah hukum positif yang berfungsi sebagai hukum acara BPSK, maka harus dilaksanakan sebagaimana mestinya, ungkap Asnal Zakri. Dengan demikian proses pelaksanaan mediasi di BPSK Bukittinggi dalam temuan peneliti sudah berjalan sesuai dengan aturan hukum yang ada.

\section{Faktor SDM Anggota BPSK Bukittinggi}

Eksistensi mediator merupakan faktor penting dalam menyelesaikan sengketa konsumen dengan jalan mediasi, disamping faktor itikad baik para pihak dan sarana pendukung lainnya.

Menurut temuan penelitian diketahui bahwa di BPSK Kota Bukittinggi terdapat 9 majelis yang masing-masing terdiri dari wakil pemerintah sebanyak 3 orang, yaitu Ali Rahman, SH.,MH, Rudolof Satri, SH, dan H. Bustamar, S.Ag., MH, 3 orang berasal dari perwakilan konsumen yaitu Gusri Elfaisal, Indra Jaya, $\mathrm{SH}$, dan Doni Syaputra, S.HI, dan 3 orang lagi berasal dari perwakilan pelaku usaha, yaitu Drs. H. Zulkifli Johneva, SH., MM, Ir. Asnal Zakri., MM, dan S.HI, Novia Almsyah,SH.

Data di atas menunjukkan bahwa apabila dilihat dari kualifikasi pendidikan majelis BPSK Bukittinggi semuanya berpendidikan sarjana, dan 8 orang diantara 9 majelis berpendidikan Sarjana Hukum dan 1 orang Sarjana Pertanian, bahkan 4 orang diantaranya berpendidikan strata 2, yakni Ali Rahman, SH., MH, H. Bustamar, S.Ag., MH., Drs. H. Zulkifli Johneva, SH., MM, dan Ir. Asnal Zakri., MM.

3 dari 9 orang anggota majelis BPSK Kota Bukittinggi sudah mengikuti pendidikan Mediator yang diselenggarakan oleh lembaga yang terakreditasi oleh Mahkamah Agung RI, yaitu 2 orang jebolan Pusat Mediasi Nasional (PNM) masing-masing Drs. H. Zulkifli Johneva, SH., MM, dan Ali Rahman, SH., MH., sedangkan H. Bustamar, S. Ag., MH mendapat Sertifikat Mediator dari Pusat Pendidikan Mediator Universitas Taruma Negara Jakarta. (Silvianti, Wawancara Pribadi,10 Juli 2017) 
Berdasarkan fakta di atas dapat dipahami bahwa dari aspek ketersediaan SDM Hukum yang mendukung tugas dan wewenang BPSK Bukittinggi sudah tersedia SDM yang memadai dan memiliki kapasitas dibidang hukum penyelesaian sengketa konsumen, sehingga hal ini dalam temuan penulis menjadi daya dukung bagi efektifnya penyelesaian sengketa konsumen di BPSK Kota Bukittinggi.

\section{Faktor Sarana dan Prasarana}

Mediasi dalam penyelesaian sengketa konsumen pada BPSK Kota Bukittinggi dilaksanakan pada ruang mediasi di kantor BPSK Kota Bukittingi jalan Perwira yang dari survey penulis, ditemukan bahwa BPSK Kota Bukittinggi berkantor di Jl. Perwira No. 184, Belakang Balok Bukittinggi.

Dari pengamatan penulis di Kantor BPSK Bukittinggi terdapat 6 ruangan, yang masing-masing ruang tamu, ruang rapat, ruang sidang, ruang pimpinan BPSK, ruang kepala sekretariat, dan ruangan serba guna, yang biasa dipakai untuk ruang shalat dan lain sebagainya.

Menurut Ali Rahman, (Wawancara Pribadi, 10 Juli 2017) meskipun belum terdapat ruang mediasi secara khusus, namun ruang rapat dan ruang sidang yang tersedia dengan perlengkapan meja yang sengaja di buat multi guna merupakan ruangan yang cukup representative dipakai sebagai tempat mediasi, dimana di ruangan tersebut para pihak dan mediator dimungkinkan untuk duduk pada posisi berhadapan dengan mediator pada posisi lainnya.

\section{Faktor Budaya Hukum}

Faktor budaya hukum para pihak yang bersengketa sangat menentukan sukses atau tidaknya mediasi. Budaya hukum sangat dipengaruhi oleh pemahaman akan peraturan perundangundangan terkait dan itikad baik para pihak yang bersengketa untuk sama-sama mencari titik temu terhadap perselisihan yang di mediasi.

Menurut Ali Rahman, dalam pengalamannya sebagai mediator dalam penyelesaian sengketa konsumen di BPSK Bukittinggi sering ditemukan adanya ketimpangan pemahaman hukum antara konsumen dengan pelaku usaha, dimana pelaku usaha biasanya jauh lebih baik pemahaman hukumnya dan sebaliknya konsumen berada dalam kondisi kurang memahami.

Namun dalam proses mediasi biasanya mediator dalam sambutan awalnya senantiasa berupaya memberikan pemahaman kepada para pihak tentang mediasi, keuntungannya dan bagaimana kedudukan para pihak dalam proses mediasi. Sambutan mediator yang menjelaskan kepada para pihak tentang apa dan bagaimana mediasi serta kelebihannya sebagai model penyelesaian sengketa dengan mengedepankan prinsip win win solution, menurut Asnal Zakri (Wawancara Pribadi, 10 Juli 2017) cukup efektif memberikan pemahanan kepada para pihak sehingga mendorong munculnya itikad baik mencari penyelesaian. Hal yang sama juga diungkapkan oleh Gusri Elfaisal (Wawancara Pribadi, 10 Juli 2017) dimana sambutan awal mediator dalam pembukaan mediasi sangat penting artinya guna keberhasilan mediasi. 


\section{PENUTUP}

\section{Kesimpulan}

Mediasi dalam penyelesaian sengketa konsumen di BPSK Kota Bukittinggi apabila dilihat dari teori efektifitas hukum Friedman yang dipertegas oleh Soerjono Soekanto, dimana efektifitas hukum ditentukan oleh faktor yuridis, faktor SDM hukum, factor sarana dan prasarana hukum, dan factor budaya hukum ditemukan sudah efektif. Dari 33 perkara yang terdaftar di BPSK Bukittinggi dalam rentang 2014- Juli 2017, 18 perkara diselesaikan dengan cara mediasi, dan 15 perkara melalui arbitrase.

Efektfitas itu didukung oleh ketersediaan aturan hukum. Meskipun diakui bahwa UU No. 8 Tahun 1999 tentang Perlindungan Konsumen dan Kemendag 350/MPP/Kep/12/2001 tentang Tugas dan Wewenang BPSK dirasa masih banyak kelemahan dan perlu penyempurnaan, namun dengan ketersediaan 9 orang SDM majelis BPSK Bukittinggi yang mayoritas berpendidikan hukum dan 3 orang diantaranya merupakan mediator bersertifikat serta adanya sarana yang cukup memadai dapat menjadi penyeimbang dan penguat sekaligus pendorong budaya hukum para pihak yang bersengketa.

\section{Saran}

Sinkronisasi peraturan perundangundangan terkait dengan tugas dan wewenang BPSK dan sosialisasi hukum konsumen secara berkelanjutan, penguatan SDM BPSK dengan berbagai perkembangan hukum dan ekonomi kekinian serta dukungan sarana dan prasana BPSK perlu selalu ditingkatkan guna terwujudnya penegakan supremasi hukum perlindungan konsumen.

\section{DAFTAR KEPUSTAKAAN}

Bukittinggi dalam Angka 2016

Kovach, K, Kimberlee, 1994, Mediation Principles and Practice, St. Paul, Minnesota: Wesl Publishing Co.

Laporan BPSK Bukittinggi, 2014, 2015, 2016, dan 2017

Mamudji, Sri, 2004, Mediasi Sebagai Alternatif Penyelesaian Sengketa di Luar Pengadilan, Jurnal Hukum Dan Pembangunan, Vol. 34, No. 3

Nolan-Haley, Nolan-Haley, Jacqueline M., 1992,Alternative Dispute Resolution. SI. Paul, Minnesota: West Publishing Co.

Nugroho, Adi, Susanti, 2015, "Proses Penyelesaian Sengketa Konsumen Ditinjau dari Hukum Acara serta Kendala dan Implementasinya", Jakrata: Kencana, Cet. Ke-2,

Praditya, 2008, Penyelesaian Sengketa Konsumen, Jakarta: Garuda

Rahmadi, Takdir, 2010, Mediasi Penyelesaian Sengketa Melalui Pendekatan Mufakat, Jakarta: PT Rajagrafindo Persada

Samsukadi, Mochamad \& Abdu,Ahmad, Efektifitas Mediasi dalam Menyelasaikan Konflik Pernikahan di Pengadilan Agama Jombang Tahun 2013-2014, Jurnal Hukum Keuarga Islam, Volume 1, Nomor 1, April 2016; ISSN: 2541-1489 (cetak)/2541-1497 (online); 1-15

Soekanto, Soerjono, 2007, Faktor-faktor yang Mempengaruhi Penegakan Hukum. Jakarta: Raja Grafindo, 
W. Moore, Christopher, 2003, The Mediation Process: Practical Strategies for Resolving Conflict, 3rd ed., San Fransisco: Jossey-Bass Publisher

Zed, Mestika \& Eddy Utama, Hasril Chaniago; Sumatera Barat di panggung sejarah, 1945-1995; Panitia Peringatan 50 Tahun RI, 1995

\section{Sumber Internet}

http://penataanruang.pu.go.id/bulletin/i ndex.asp?mod $=\_$fullart\&idart $=94$, diakses tanggal 12 Juli 2017

\section{Narasumber Wawancara}

Asnal Zakri, Anggota BPSK Kota Bukittinggi 2011-2017

Ali Rahman, Anggota BPSK Kota Bukittinggi 2011-2017
Alizar, Kepala Sekretariat BPSK Kota Bukittinggi
Gusri Elfaisal, Anggota BPSK Kota Bukittinggi 2011-2017
Zulkifli Johneva, Anggota BPSK Kota Bukittinggi 2011-2017
Silvianti, Sekretariat BPSK Kota Bukittinggi

Peraturan Perundang-undangan

UU No. 8 Tahun 1999 Tentang Perlindungan Konsumen

Keputusan Menteri Perindustrian dan Perdagangan No. 350/MPP/Kep/12/2001 Tentang Tugas dan Wewenang Badan Penyelesaian Sengketa Konsumen 